\title{
16
}

\section{JOHN WARR AS COMMANDING OFFICER: HIS APPROACH TO THE WAR}

\author{
Max Carroll, Peter Isaacs, \\ Michael Deak (Michael von Berg) and Mark Warr
}

\section{Editors' introduction}

In any infantry battalion the key person is the commanding officer (CO). His position is very challenging to hold, demanding knowledge, operational skill, judgement and humanity in directing the efforts of several hundred men in a complex and dangerous environment. COs vary in their effectiveness and how they are regarded by the men under their command. In 5th Battalion, the Royal Australian Regiment (5 RAR), the overwhelming consensus, both while we were on operations in Vietnam and over the several decades since then, was that we were very lucky to have had John Warr to lead us. In this chapter, three of the officers who related most closely with him on operations, and one member of his family, present their views from different perspectives to make clear the reasons for his high place in our esteem and affection. His personality and his leadership are discussed by those who knew him best as our commander in war. 


\section{Max Carroll}

I was still at the Staff College, Queenscliff, when my posting to 5 RAR as a company commander was promulgated in late 1965 . I was very satisfied. I had been requesting a return to regimental duties as I had not served in a regular battalion since late 1959. I had done my time as a Citizens Military Forces adjutant, an instructor at an Army Headquarters School and a Grade 3 staff appointment before Staff College. It was common knowledge that 5 RAR was the logical replacement for 1 RAR in Vietnam, so I also had active service to look forward to. Many of my infantry student colleagues, who were destined for a variety of Grade 2 staff appointments on various headquarters, were rather envious.

On one of my visits to Canberra, where my family had remained while I was at Queenscliff, I paid my respects to the Directorate of Infantry at Army Headquarters. I had the dual intent of not only saying 'thank you very much', but also of finding out all I could about my new CO, Lieutenant Colonel John Warr, who was a complete stranger to me. I learnt as much as the guarded staff officers were prepared to tell me, but it was enough to establish that he had a good reputation, otherwise he would not be commanding an Australian Regular Army battalion. He was an Royal Military College graduate of 1947, had served in Japan in the British Commonwealth Occupation Force and then in Korea with 3 RAR, where he had been badly wounded. He had also done an exchange appointment with the Canadian Army. I was looking forward to meeting him.

It was Wednesday morning, 5 January 1966, when I reported for duty with 5 RAR at the old Holsworthy Barracks. It was like coming home. I had last been there in 1957 with 3 RAR before going to Malaya. The immaculately turned out regimental policeman who gave me directions at the front gate was a clear indication of the high standard of this battalion, and this in turn meant a good CO. I was duly ushered in to meet John Warr and he came around from behind his desk to greet me. I knew that he was appraising me, as I was him, but his keen eyes, ready grin and firm handshake made for a relaxed first meeting. I instinctively liked this bloke and knew I would enjoy working with him. In easy chairs over a cup of coffee he briefed me on all aspects of the battalion. We discussed current strength, reinforcements due, the likelihood of going to Vietnam, and the heavy training ahead. Then he got around to telling me what I would be doing. I was to be officer commanding (OC) Support 
Company. He must have noticed my disappointment, as I badly wanted a rifle company. He went on to say that, in addition to Support Company, I would be battalion operations officer and battle second in command (2IC). This was a system that 1 RAR had necessarily adopted from being part of 173 Airborne Brigade. As we would be replacing 1 RAR, we would also be following the same system. He added that the job would be demanding and meant writing all the battalion operation orders, for which staff training was essential. When we were deployed, I would be running the battalion command post and the operational radio command net. He concluded by saying that as only himself, Stan Maizey - the 2IC - and I were Staff College graduates, perhaps I now understood why I had arrived straight from Staff College. This latter remark was delivered with his disarming grin! And I had been checking him out before joining. It was obvious to me then that he had been in close liaison with the Director of Infantry and subsequently I had won the lottery! And so began a very close, professional relationship, as well as a lifelong friendship.

John Warr was a commander with high standards, which is as it should be. He knew what he wanted, clearly expressed this in his orders and expected his subordinates to ensure these standards were met. Training for war is always at a hard, ruthless tempo, particularly so when it is known that in several months' time shooting to kill will be the norm. The time from when we were officially warned in late January 1966 for deployment to Vietnam, until when our advance party left on 20 April 1966, was short and so could not be wasted. Between late January and early February we had several hundred reinforcements march in who had never worked together at their final platoon or company levels, let alone as a battalion. Several new officers marched into the battalion, including myself, who had to get a grip rapidly on things. This was the time to get things right because errors here could be corrected without loss of life. We succeeded because John Warr was everywhere: observing, talking and listening to all ranks, and quietly and shrewdly assessing their strengths and weaknesses. He was a good manager who got the best out of people. He rode with a loose rein, but God help anyone, who, after a fair warning, didn't measure up. They left! This particularly applied to officers, warrant officers and senior non-commissioned officers (NCOs), as his soldiers' lives depended on these people. He also continued this policy in Vietnam and we were a tightly welded unit, efficient, confident and proud when we departed from Australia; and our $\mathrm{CO}$ was held in high esteem by all ranks. 
Vietnam put all the training to the test; we hit the ground running and never looked back. There were difficult, often tense periods, particularly during prolonged operations, when strain and weariness were constant companions; it was then that the CO's calm leadership prevailed. He led by example and I, as his senior operations officer who worked closely with him in the planning and execution of our war, often saw his coolness under stress. I admired him greatly and learned a lot from him. He had an easy, laid-back style with not only me but other officers on the headquarters who worked closely with him, such as Stan Maizey, the 2IC, Peter Isaacs, the adjutant/assistant operations officer, and Bob O'Neill, the intelligence officer. He would often pose questions which invited discussion, during which he would pick our brains. Obviously, he was testing a plan he had in his head for weaknesses when exposed to other viewpoints, and he always listened carefully to what was said. After he had formulated his plan for an operation he would then pass it to me to work out the fine detail, coordination and writing of the draft operation order. This I then cleared with him before the final production of the order, which he then issued at his Orders Group. I liked working for him.

I only disagreed with one of John Warr's operational decisions, and that was during Operation Canberra, referred to in Chapter 6 and by Peter Isaacs in this chapter. I felt then and still do, that he should have allowed Bruce McQualter's B Company attack to proceed. 'The Role Of An Infantry Battalion', published in The Division in Battle Pamphlet No 1 is unequivocal, and reads:

To seek out and close with the enemy, to kill or capture him, to seize and hold ground and to repel attack, by day or night, regardless of season, weather or terrain. ${ }^{1}$

B Company had successfully found the enemy, were undetected and were ready to go in. Bruce was bitterly disappointed at being pulled back. We shared his disappointment, particularly as he had the key element of surprise in his favour. I knew him well, having served together twice before. He was a competent leader, with a superb company which he had trained well. If he said he could successfully attack, I believed him. However, the CO's decision was final, so we obeyed and got on with the war, without recriminations.

1 Australian Military Board, The division in battle, nos 1-11, Pamphlet No 1: Organisation and tactics, Army Headquarters, Canberra, 1966, p 14. 
John Warr's relations with the task force commander, Brigadier David Jackson, were good and easy, as the task force commander allowed both of his battalion commanders a fair bit of latitude. David Jackson was well experienced in Vietnam, having commanded the Australian Army Training Team Vietnam, then the Australian Army Force Vietnam, before assuming command of 1st Australian Task Force (1 ATF). He ran a good Task Force, although he was severely restricted in terms of what could be done by only two battalions. His successor, Brigadier Stuart Graham, inherited the same problems. He too was easy to work with; our relations with the Task Force headquarters staff also improved when our 2IC, Stan Maizey, moved there to become the task force operations officer.

I feel I must offer some words of support for Stuart Graham, who has been maligned by a host of armchair warriors with perfect hindsight, for his decision to build the barrier minefield from Dat Do to the sea. In the planning stage, he sought the opinions of both John Warr and Colin Townsend, his two battalion COs, plus Brian Florence, the OC of 1 Field Squadron, Royal Australian Engineers. All were against it, pointing out the time-honoured principle that an obstacle must be covered by observation and fire. However, the Vietnamese province chief guaranteed to provide this cover. Graham next put his proposal to higher headquarters, both Australian and US, and NO ONE OBJECTED! His hope was that the obstacle would free his limited infantry resources for use elsewhere. In the event, the Vietnamese failed to fulfil their commitment, which was a bitter lesson learnt! The Army of the Republic of Vietnam (ARVN) let him down! Again, I am not aware of any resultant ill feelings between Graham and his subordinate unit commanders. We, including John Warr, accepted his decision and got on with the job.

A few closing words on John Warr. He was a gentleman in his dealings with others, and was a gentle man by nature, although there was a strong band of steel beneath the quiet, smiling exterior. It was indeed remarkable that a man who did not drink alcohol, smoke, swear or lose his temper should be held in such high regard and esteem by the rather wild, hardened and at times 'hairy-heeled' bunch of officers, warrant officers, NCOs and men who were 5 RAR. We all respected his professional competence, but we also knew that he cared deeply for his battalion, and this was reflected in our sincere feelings for him. We all agreed that we were indeed lucky to have him as $\mathrm{CO}$. 


\section{Peter Isaacs}

I joined the Australian Army from the UK in January 1963 and was posted to 1 RAR at Holsworthy, NSW. At the time, John Warr was OC B Company. As I was a platoon commander in E Company, I didn't really get to know him at all, although I do remember him arranging for a Sydney stockbroker to come and address the officers one evening in our mess at Gallipoli Barracks. It was at a time when the darling of the Sydney Stock Exchange was the Kalgoorlie-based mining company Poseidon, and everyone with a few bob to invest was hoping to make a fortune in Australia's burgeoning mining industry. I think it did, however, indicate John's interest in business, an interest that he was to develop after he retired from the army.

It wasn't really until 1964 that I got to know him. He had been appointed the senior administration and logistics staff officer on 1 RAR Battalion Headquarters (BHQ, which was multi-functionally organised and staffed to operate as a Battle Group HQ within the Pentropic divisional structure) where I had become a junior operations staff officer. In late 1964, orders were received to reform 1 RAR into a smaller 750-man infantry battalion suitable for operations in South-East Asia, and create 5 RAR from the 'leftovers', it was largely John's responsibility to bring this upheaval about. As was his nature, he set about it with his customary enthusiasm and eye for detail but was probably as disappointed as I was when informed that neither of us would remain with 1 RAR during its forthcoming deployment to South Vietnam, scheduled to occur in April 1965.

I'm sure that John was doubly disappointed to learn that he was not to become 5 RAR's first CO; that honour going to Peter Oxley who was then the military attaché in Saigon and not due to join the battalion until May 1965. 1 RAR and 5 RAR separated at the beginning of 1965 and John assumed 'administrative command' of 5 RAR when the battalion was formally established on 1 March. This arrangement continued after 1 RAR's departure for South Vietnam in April and until Peter Oxley joined and assumed command in May.

Recognition of John's hard work and unstinting efforts came with the announcement that he was to be promoted to command of the battalion in September. Although it was assumed that 5 RAR would relieve 1 RAR in South Vietnam in April 1966, this was not confirmed until January. 
John prepared the battalion for war with a combination of realism for the complexity of the task at hand, toughness when necessary and an understanding of the strengths and weaknesses of his officers, warrant officers and senior NCOs. Of the 16 officers who had formed the battalion in March 1965, only nine of the originals remained when the full complement of 37 embarked with the battalion for South Vietnam in April a year later. This enormous throughput of officers and a seriously understrength cadre of experienced warrant officers and senior NCOs occurred at a time when the battalion was being brought up to strength with the first drafts of partly trained national servicemen. By the time the battalion embarked for Vietnam, these comprised approximately 50 per cent of the unit's strength. It was a severe handicap that John overcame through persistence with the various tiers of higher headquarters. He was able to obtain for the battalion the personnel and the equipment needed from what turned out to be a chronically under-resourced ordnance system. The reality was that in 1965-66, the Australian Army was ill-prepared for the task of mobilising the forces that politicians were committing to a war in South-East Asia.

As adjutant and assistant operations officer, it was my privilege to serve John closely and to develop a friendship that continued until he died in 1999. I don't ever recall seeing John lose his temper, nor do I recall him raising his voice. He had an easygoing style and, unlike some COs I have known, was always approachable. He encouraged discussion, the exchange of views and ideas. We who served him did so to the best of our abilities because we all recognised his decent human nature, understood what he wanted to achieve and were determined to achieve it with him.

I have heard it said by a former senior NCO that he considered 5 RAR to have been outstanding because John Warr commanded the battalion and his officers led from the front. He cited the unusually high number of fatal officer casualties as evidence for this. His view of our officer casualties, although quite widely held, does not reflect the reality of the actual circumstances. The best infantry officers lead from the front when circumstances demand, but the five who were killed were all victims of mines which are indiscriminate. Nevertheless, they were certainly among the best officers we had.

In Chapter 6 there is an account of a near collision on 8 October 1966 between B Company and some 30 members of the Viet Cong (VC) 274 Regiment. In deciding not to allow B Company to attack what was 
probably the headquarters of this VC Regiment, but rather to call in massive artillery and offensive air support, I believe John was following the advice he had been given by Major General Tom Daly on the eve of our departure for South Vietnam.

Had we attacked and killed or captured 274 Regiment, it would have been an outstanding tactical victory, but would it have had a major impact on the war? Of course not, but we would certainly have taken casualties, possibly in significant numbers if, as 11th-hour intelligence had revealed, B Company had encountered a much stronger force than was revealed by their initial contact. Men are alive today and their descendants too because of John Warr's decision on that day. It was not a war of Australia's national survival, nor of great strategic importance. At the time, I thought John's decision was wrong, but with the benefit of hindsight, I cannot now criticise him for that decision.

Like any man, John favoured some people more than others and, in my opinion, he was at times hard on some of his officers who were the least deserving of criticism. Nevertheless, he dealt decisively with those officers, warrant officers and senior NCOs who, prior to embarkation and in the early months of our deployment, failed to meet the high standards he set. Within BHQ John had several gifted individuals, namely his successive seconds in command Stan Maizey and Ivor 'Blue' Hodgkinson, operations officer and OC Support Company Max Carroll and, from August 1966, intelligence officer Bob O'Neill. Stan and Blue ran the administration of the battalion with energy and flair, and relieved John of what was a major headache prior to and during the first six months of our deployment. Max was a master of staff duties and wrote the complex plans to implement John's operational concepts. He drove the operations and provided the 'aggression'. Bob was the analyst and thinker, and was highly influential on John's decisions as to the concept of operations. This was significant because until the arrival of Brigadier Stuart Graham as 1 ATF Commander in January 1967, Brigadier David Jackson had permitted both battalion commanders considerable freedom of action in deciding on their operational priorities. From the army's experiences in the Malayan Emergency, John had developed a good understanding of the concept of counter-revolutionary warfare. He did not believe that pursuing VC Main Force units all over the province was either feasible at the time, or likely to produce the necessary results in terms of bringing security to the population and separating them from the VC. 
5 RAR developed the concept and procedures for cordon and search operations and conducted several highly effective examples. They were not dramatic, headline-grabbing events. Barbed wire enclosures containing fearful and uncooperative villagers morphed into white cloth tape enclosures in which villagers awaiting questioning were fed and entertained with music played by the Battalion Band! It was not because John necessarily believed that Vietnamese civilians should be treated gently; after all, many, if not most, were VC sympathisers and some were active supporters. It was mainly because better results were obtained by treating them with kindness, and many embedded VC cadre members were thus successfully rooted out of the communities which they had hitherto controlled.

Towards the end of our tour, we began the construction of what became the infamous 'fence'; the 11-kilometre, mined wire barrier between the Horseshoe feature and the coast. John had misgivings about the concept and raised them with Brigadier Graham, but I don't recall his expressing them within the battalion. We got on with it and built the fence with the assistance of our supporting Engineer Field Squadron who had the unenviable task of laying more than 30,000 mines. Brigadier Graham's plans were fully supported by his operations and intelligence staff and approved by the Commanding General of II Field Force Vietnam (IIFFV) to whom he reported. So far as I am aware, no objection was raised by Commander, Australian Force Vietnam, in Saigon. If the Vietnamese military authorities had fulfilled their obligations, the $\mathrm{VC}$ might have been prevented from lifting so many mines and using them against our successors. Graham didn't have the benefit of hindsight that his many critics have enjoyed.

During the year, we took 26 fatal casualties, some the results of our own errors, and a further 79 were wounded in action. Our grief was expressed through battalion parades at which our padres gave thanks for the lives of the fallen and their service to Australia. If John was affected by the casualties, he didn't show it. Perhaps he drew strength from his Christian Science faith.

It was a privilege to have served John for almost two years in both peace and war. I learned much from his example and from those individuals I mentioned earlier. Battalions reflect their commander's style and hence 
John Warr led a battalion that was second to none. The late Ron Hamlyn, who commanded both Administration Company and B Company after Bruce McQualter was killed, summed it up when he said:

Every night for the next few years I used to thank the Lord for giving 5 RAR John Arnold Warr as commanding officer; the most compassionate and caring man I ever met.

\section{Michael Deak (Michael von Berg)}

Lieutenant Colonel John Warr and I go back to the days of 1 RAR (196264) before I was commissioned. On more than one occasion I was a source of some concern in the battalion for the occasional social indiscretion and being somewhat high spirited. When I was selected for the Officer Cadet School, Portsea, it surprised John Warr and many others, but none more so when I graduated in December 1965 and was posted to 5 RAR in January 1966 where John Warr was now the CO. Although now commissioned, my past exploits could have very easily curtailed my new career before it had time to start. The CO, with one phone call or stroke of the pen, could have banished me from the battalion to some lesser role, as the battalion was going to war, but he didn't and that's where our journey really began. He must have seen something in me despite my past misdemeanours. A CO with less patience and understanding may not have been as accommodating.

Once deployed in Vietnam, I took my responsibilities as a platoon commander in A Company very seriously, particularly on operations and in looking after my men, who were a great bunch. But there was friction between the OC A Company and myself, mostly on tactical and operational issues that I will not go into. Suffice it to say that my time in the company was limited after the OC A Company reported me for gambling with the troops. This resulted in my fronting the task force commander. The $\mathrm{CO}$ could have once again dispensed with my services but instead transferred me to Support Company and the Anti-Tank Platoon under the watchful eye, guidance and inspirational leadership of Major Max Carroll, for whom I had enormous respect. Respect is paramount in the relationship between any company commander and his platoon commanders. Where there is no respect there is no trust, and happily these two very important characteristics in Max were there in abundance, which assisted me enormously in my new role. 
When the $\mathrm{CO}$ tasked me to establish the battalion's Reconnaissance Platoon, I was delighted and honoured to be given the opportunity and determined to do whatever was possible to not let him or the battalion down. My fellow officers and the battalion deserved nothing less. In many ways that task, its responsibilities and the wonderful men I had the honour to lead have made me what I am today.

The $\mathrm{CO}$ was respected and admired by the soldiers in the battalion, who referred to him affectionately as 'Wingy', because as a platoon commander in Korea a mine incident had left him with a right arm unable to be fully extended. Given the penchant for Australian soldiers to give everyone and everything a nickname, Wingy was born. The soldiers not only respected and admired Wingy, they were very fond of him because they knew he cared and no matter where he came across the soldiers, he would always have that wry smile to put diggers at ease. More importantly, he would engage with them meaningfully in asking about their families and about themselves. He always placed a gentle hand on the shoulder when thanking someone for a job well done.

What I really respected about John Warr as a battle commander and as a leader was that the BHQ group was always in the field with us, doing the hard yards, the same as everyone else in the battalion. They shared with us liana and thorny 'wait-a-while' vines that were very difficult to get through, bamboo thickets and impregnable jungle that were just as much a hindrance and as annoying to the $\mathrm{CO}$ as they were to us in the rifle companies. As the battle commander, if one of the companies said it was facing rough going, the $\mathrm{CO}$ didn't have to be convinced, sitting back in a static command post or floating about in a Sioux helicopter. He led from the front and when we were wet, tired, exhausted and miserable there was a good chance the $\mathrm{CO}$ shared our discomforts.

In the Reconnaissance Platoon debriefs that I underwent with the CO and Bob O'Neill, at times I was disappointed that our patrols had not revealed anything of major importance. They both advised me that negative information is often positive information, and Bob O'Neill would put it into an intelligence-gathering context. All information, positive or negative, was appreciated and the $\mathrm{CO}$ would take this all on board and then question me about my men, their health and disposition. This would be followed by a beer in the mess where the $\mathrm{CO}$, as a teetotaller, would have a can of Coke before I went down to have a drink with my 
blokes in the diggers' boozer. I have had many commanders who claimed they cared for their soldiers. With John Warr there was no doubt or ambiguity; I knew he really did care. A huge difference!

This feeling of someone really caring is particularly relevant when you are out on patrol somewhere and all hell breaks loose. Knowing that all available support is there for you to use when needed gives you great confidence as a young platoon commander in fighting the fight and extracting your blokes from a tough situation if warranted. After a very difficult contact where 'Bluey' Twaits was badly wounded, resulting in the loss of his leg below the knee, the very next day John Warr arranged for me to fly over to see Blue in 36 Evacuation Hospital, because John knew we were all very concerned about him.

It's very difficult to describe the fondness and enormous respect I have for John Warr still to this day. Although he saved my arse on more than one occasion, I think the basis for my feelings is much more than that. It's both spiritual and humanistic, where John epitomised everything that is so special and unique about old Christian values. Forgiveness, empathy, compassion and a brotherly love that was evident in so many ways. This brotherly love was felt throughout the battalion, whenever we lost good officers and men. I know John Warr felt it deeply, but through his strong personal beliefs, strength of character and quiet leadership, he kept us together to continue in our respective roles. He certainly had a major effect on me, and some of his principles and ethics have remained with me to this present day. Don't always look for the bad, look for the good; don't close your mind off because it's not your idea; if you believe in something, pursue it strongly; be approachable and honest with your subordinates; and, most importantly, be fair in your judgements. It was a great honour and a lot of fun, mostly at my expense, in serving a very special CO, mentor and leader.

\section{Mark Warr}

My father, the man the battalion got to know in Vietnam and after, I believe was very much the same man within his family. His motives and thoughts were always first for those around him, be it battalion or family, and was constantly considering how he could help improve things for them. In the last 10 years I have become more interested in the Vietnam War, and the more I read and learn about it, the more impressed I am by 
how and what 5 RAR achieved while there. When I see photographs of John in Vietnam, he seems particularly content, and while there was much sadness and devastation experienced, John was given pretty much free rein on how best to do the job. Every decision was motivated to help not only his men, but also the Vietnamese people. Some publications I have read mention the differences of view that John had about Brigadier Stuart Graham's decision, when Graham had decided to lay land mines. John's primary concerns would have been not only for his men and the Australian battalions that would come after, but also for the local Vietnamese people, who he felt would be adversely affected by this development.

John never liked how some in the media, particularly in America, would gauge military success by the highly inflated enemy body counts. He didn't see this fraudulent approach as helpful to winning the war in Vietnam. While he could be confrontational if necessary, his decisions were intended primarily to win the Vietnamese people over and to protect his men.

I think his refined cordon and search operations exemplify his thinking on how to conduct this kind of war. Under the circumstances, he saw it as the safest way of sifting the $\mathrm{VC}$ out of the villages, and protecting the men of 5 RAR, while bringing the villagers onside. When I see film footage and hear about the battalion's band playing in the villages during these operations, I think, yep, that's John. He's doing whatever he can to make the situation more tolerable for the Vietnamese, but I've sometimes wondered what the villagers thought of the music.

Another incident that showed his need to protect his men was covered in Bob O'Neill's book Vietnam Task. ${ }^{2}$ B Company had about 30 VC covered, in the Nui Thi Vai hills, and were in a perfect position to attack them. Bruce McQualter was waiting on the order from John to go ahead when John was given intelligence at that very moment that a large unit of VC could be in the vicinity. It was fresh intelligence and his mind would move quickly in situations like this. I understand that it only took a few moments for him to consider the implications and decide that the task was likely to be too big for the isolated B Company alone. He would never put his soldiers' lives unnecessarily at risk.

2 Robert J O'Neill, Vietnam Task: The 5th Battalion, Royal Australian Regiment, Cassell Australia, Melbourne, 1968. 
Another incident that I learnt about was related in the battalion's medical officer Tony White's book Starlight. ${ }^{3}$ C Company were performing a cordon and search in An Nhut village when a mine was set off, killing three and wounding five more. John was bending over Major Don Bourne, talking to him and giving him words of comfort. Tony knew that Don had already died but didn't have the heart to tell John. It was apparently quite a few moments until he realised Don was dead. In the words of Tony, 'the look of pain and dismay that came over his face at that moment was, for me, one of the most poignant moments of the war'. ${ }^{4}$

How John felt doesn't surprise me. The achievements of 5 RAR during this tour I think are very much still a great unsung story. The operations of the Australian Army, and its tactics and strategies, had to change to meet a new kind of warfare. But on top of that, 5 RAR were the first in Vietnam to be manned by a high proportion of conscripted national servicemen. The controversy over using these men in this war was very divisive in Australia and there were also problems caused, for example, by the Seamen's Union when they refused to load ships with supplies necessary for the war front. 1 ATF eventually needed to beg, borrow and occasionally 'liberate' from the Americans some of the equipment they needed. When 5 RAR arrived at Vung Tau in 1966, it was estimated that about 70 per cent of the population of Phuoc Tuy Province in South Vietnam was effectively under some form of VC control. By the time they left, one year later, that level of control had been reduced to about 15 per cent. John always supported the doctrine that it is difficult to win a counter-insurgency war without winning the hearts and minds of the people. The battalion began that process very effectively in the relatively short time they were in Vietnam.

John was an extremely empathetic person who would never back down from a challenge but would take it on enthusiastically. He would revel in the situation, and he gave any chance he could to the people in his battalion to do the same. He would work with them and create clear goals that met the challenges of the battalion as a whole. It was all the things that I learned to believe a good leader should do. But knowing John as my father, I do not find this surprising.

3 Tony White, Starlight: An Australian Army Doctor in Vietnam, CopyRight Publishing, Brisbane, 2011.

4 White, Starlight, p 144. 
In my opinion, I can't imagine a better person to lead 5 RAR through so many challenges, from before the time they left Sydney until their return, having achieved so much. I vividly remember attending Government House in Sydney when John was presented with the insignia of the Distinguished Service Order. From the moment John received that award I can remember him telling anybody who asked about it that it recognised the achievements and work done by the whole battalion. Whenever I was with him, and the same question was asked, he would give the same or similar answer for the next 30 years. He never stopped praising the efforts of the whole battalion and making light of what he had done.

Bruce Ruxton was the president of the Victorian Returned and Services League (RSL) for many years after the war. He was John's brother-in-law and my maternal uncle. I noticed over the years that Vietnam veterans were negative towards the RSL and complained that it had done little for them on their return. I used to think that it must be something to do with the branch to which they belonged. In Bruce's later years he was living in Noosa, and I visited him. I remember telling him that I found the Vietnam War extremely interesting and asked if he knew anybody I could visit, to tell me more about events there. He looked at me sheepishly and appeared somewhat embarrassed. Anybody who knows Bruce, or knows of him, is aware that it takes plenty to move him. Looking quite moved, he answered, 'I don't know much about that period at all, Mark'. I think he realised the lack of recognition he and the RSL had given Vietnam veterans, and it had become a cause for deep regret to him.

I was fortunate enough to travel to Vietnam several years ago, and even more fortunate to have been taken around the old base of Nui Dat, and to have visited the original site of the Battle of Long Tan and the port of Vung Tau, by Graham 'Breaker' Cusack. Graham was a second lieutenant with 6 RAR and had been that battalion's command post duty officer on the afternoon of the Battle of Long Tan. He was the first to hear 'contact' by $\mathrm{D}$ Company and listened in to the constant radio communications with them during the battle. When he took me and my partner Sue to Long Tan, he could still remember word for word the radio conversations he had had that day. It was 2011, almost 45 years later, but he described it like it was yesterday. I am very grateful to Graham for the experiences of that day, but even more grateful to have been given the father I had in John Warr, and to have learnt so much about the extraordinary 5th Battalion of the Royal Australian Regiment that he commanded in 1966-67. 
This text is taken from Vietnam Vanguard: The 5th Battalion's Approach to Counter-Insurgency, 1966, edited by Ron Boxall and Robert O'Neill, published 2020 by ANU Press, The Australian National University, Canberra, Australia.

doi.org/10.22459/VV.2019.16 